\title{
A Cross-scale Model Coupling Approach to Simulate the Risk-reduction Effect of Natural Adaptation on Soybean Production under Climate Change
}

\section{Dongli Fan ${ }^{1}$ Qiuying Ding ${ }^{1,2}$ Zhan tian $^{2} \quad$ Laixiang Sun $^{3,4}$ Guenther Fischer $^{4}$}

1) Shanghai institute of technology, Shanghai 21400, China, E-mail: dqyaaron@163.com.

2) Shanghai climate center, Shanghai meteorological bureau, Shanghai 20030, China, E-mail:zhantzy@gmail.com.

3) Department of Geographic Sciences, University of Maryland, College Park 20742, USA, E-mail:Lsun123@umd.edu.

4) International Institute for Applied System Analysis, Laxenburg 2361, Austria, Email: Fischer@iiasa.ac.at.

\section{ACKNOWLEDGEMENT}

This work is supported by the National Natural Science Foundation of China (Grant Nos. 41371110) and China Meteorological Administration (Grant No. CCSF201330 and CCSF201112). 
This is the version of the article accepted for publication in Human and Ecological Risk Assessment: An International Journal published by Taylor \& Francis. Available at: http://dx.doi.org/10.1080/10807039.2016.1221308

Accepted Version downloaded from SOAS Research Online: http://eprints.soas.ac.uk/23026/ 
This is the version of the article accepted for publication in Human and Ecological Risk Assessment: An International Journal published by Taylor \& Francis. Available at: http://dx.doi.org/10.1080/10807039.2016.1221308

Accepted Version downloaded from SOAS Research Online: http://eprints.soas.ac.uk/23026/

\title{
A Cross-scale Model Coupling Approach to Simulate the Risk-reduction Effect of Natural Adaptation on Soybean Production under Climate Change
}

\begin{abstract}
\end{abstract}
This study establishes a procedure to couple Decision Support System for Agrotechnology Transfer (DSSAT) and China Agro-ecological Zone model (AEZ-China). This procedure enables us to quantify the effects of two natural adaptation measures on soybean production in China, concern on which has been growing owing to the rapidly rising demand for soybean and the foreseen global climate change. The parameters calibration and mode verification are based on the observation records of soybean growth at 13 agro-meteorological observation stations in Northeast China and Huang-Huai-Hai Plain over 1981-2011. The calibration of eco-physiological parameters is based on the algorithms of DSSAT that simulate the dynamic bio-physiological processes of crop growth in daily time-step. The effects of shifts in planting day and changes in the length of growth cycle (LGC) are evaluated by the speedy algorithms of AEZ. Results indicate that without adaptation, climate change from the baseline 1961-1990 to the climate of 2050s as specified in the Providing REgional Climate for Impacts Studies-A1B would decrease the potential yield of soybean. By contrast, simulations of DSSAT using AEZ-recommended cultivars with adaptive LGC and also the corresponding adaptive planting dates show that the risk of yield loss could be fully or partially mitigated across majority of grid-cells in the major soybean growing areas.

KEYWORDS: Climate change adaptation; soybean production; model coupling, China RUNNING HEADING: Cross-scale Model Coupling and Assessment of Adaptation Measures 
This is the version of the article accepted for publication in Human and Ecological Risk Assessment: An International Journal published by Taylor \& Francis. Available at: http://dx.doi.org/10.1080/10807039.2016.1221308

Accepted Version downloaded from SOAS Research Online: http://eprints.soas.ac.uk/23026/

\section{INTRODUCTION}

Growing population, expanding affluence, rapid urbanization and changing dietary preferences are increasing global demand for food and fuel products (Foley 2005; Kastner et al. 2012). The most significant development in affluence, urbanization, and dietary change has been observed in China and East Asia in recent decades and the trend is expected to continue and further extend into other developing regions in near future. As an important source of protein for humans and livestock, global consumption of soybean products has increased by more than 200 million tons (MT) since 1970 (FAO 2010, 2013). The consumption in China has grown remarkably fast and the increments have been met by imports. As a matter of fact, Chinese import of soybean reached more than 70 million tons in the market year of 2013-14, which accounted for more than $60 \%$ of the total world exports and more than $85 \%$ of domestic consumption. ${ }^{1}$ Such excessive dependence of Chinese soybean supply on international market has attracted great concerns on the domestic supply capability and the associated food security risk for China. This supply capability concerns are further troubled by the foreseeing change in climate because soybean production is sensitive to climate and weather conditions. To address the concerns on soybean production capability under future climate change, this paper aims to conduct an advanced assessment which takes into account two natural adaptation measures on soybean production in China. This assessment is carried out by a model coupling procedure between the Decision Support System for Agrotechnology Transfer (DSSAT) and the China Agro-ecological Zone model (AEZ-China). The findings indicate that there will be large room for active and systematic adaptations by farmers and policy makers in

\footnotetext{
${ }^{1}$ Global Trade Atlas at http://www.gtis.com/english/GTIS_GTA.html.
} 
This is the version of the article accepted for publication in Human and Ecological Risk Assessment: An International Journal published by Taylor \& Francis. Available at: http://dx.doi.org/10.1080/10807039.2016.1221308

Accepted Version downloaded from SOAS Research Online: http://eprints.soas.ac.uk/23026/

mitigating the risks and uncertainty posed by climate change to soybean production in China.

The sensitivity of soybean production to climate and weather conditions has been well-documented. For example, Ferreira et al. (2011) and Calzadilla (2014) show that slight changes in climate resources, particularly temperature and precipitation, can lead to remarkable effects to soybean production. Because of this sensitivity, the impact of climate change on soybean production has drawn considerable research attention. The existing publications indicate that drought and $\mathrm{CO}_{2}$ concentration influence soybean production and quality (Thomas et al. 2003; Hao et al. 2009; Sinclair et al. 2007). Global warming can be conducive for soybean growth in high-latitude areas, such as in Northeast China where the growing period and suitable area have been extended during the last few decades and will continue to be extended under the scenarios of future climate change (Chen et al. 2012). Related studies have reported that global warming is beneficial to soybean planting in high-latitude areas, particularly in Northeast China (Xiao et al. 2007), but is disadvantageous to low-latitude areas, such as in the middle and lower Yangtze River basin (Hao et al. 2010; Shi et al. 2001). However, these assessments do not take into account the adaptation measures of soybean farmers.

Developing and applying modern and effective risk analysis tools can help to better understand and control the disadvantageous effect of climate change on human society in general and food security in particular (Drager et al. 2014; Hao et al. 2012; Yin et al. 2011). Researchers have developed numerous modeling tools to estimate the risks posed by climate change on soybean production. These modeling tools can be divided into two main categories, namely, dynamic crop models and agro-ecological productivity models (Tian et al. 2012). The Decision Support System for 
This is the version of the article accepted for publication in Human and Ecological Risk Assessment: An International Journal published by Taylor \& Francis. Available at: http://dx.doi.org/10.1080/10807039.2016.1221308

Accepted Version downloaded from SOAS Research Online: http://eprints.soas.ac.uk/23026/

Agrotechnology Transfer (DSSAT) model, which is a dynamic crop growth model, and the Agro-ecological Zone (AEZ) model, which is an agro-ecological productivity model, have been extensively used in the impact assessment literature for agriculture. DSSAT is a site- and crop-specific mechanism model typically employed to simulate crop growth and development. By contrast, AEZ is built on more simplified biophysiologic dynamics and can speedily assesses the impact of climate, soil, and other factors on production potentials across grid-cells in a region. Coupling of the two models has been successfully carried out by Tian et al. $(2012,2014 \mathrm{a}, 2014 \mathrm{~b})$ for the purpose of evaluating the production capability of wheat and rice production under historical climate conditions in China. The major objective of this study is twofold. First, it seeks to extend the application of this coupling method to the case of soybean production under future climate conditions in China. Second, it explicitly takes into account the effects of two specific natural adaptation measures, i.e. adopting adaptive cultivars characterized by adaptive length of growth cycle (LGC) and the associated adaptive planting dates, on soybean production under the condition of climate change in China.

Existing field studies have reported that farmers are aware of climate risks in the context of observed climate change during the last several decades and have utilized adaptive and mitigating measures (Sahu 2013; Li 2010). Observations from field experiments have demonstrated that soybean yields are sensitive to planting dates and the LGC features of cultivars (Marzban et al. 2011). It was reported that in response to thermal stress caused by warming climate, an early sowing date in the North Central US Corn Belt and delayed sowing dates in India can significantly mitigate the detrimental effects of thermal stress on soybean yields (Setiyono et al. 2010; Mall et al. 2004). The choice of the LGC feature of cultivar is also a critical management decision 
This is the version of the article accepted for publication in Human and Ecological Risk Assessment: An International Journal published by Taylor \& Francis. Available at: http://dx.doi.org/10.1080/10807039.2016.1221308

Accepted Version downloaded from SOAS Research Online: http://eprints.soas.ac.uk/23026/

for successfully mitigating the yield-loss risks posed by climate change on soybean production (De Bruin 2008; Liu et al. 2008). Our simulations in this study will focus on these two adaptive measures. In addition, we will not only conduct the assessment at each of the 13 stations, but also at the grid-cell level across the Northeast region and the Huang-Huai-Hai Plain, the two major soybean production regions in China.

The coupling of the DSSAT and AEZ models is essential for running the assessment across grid-cells. In this way, we can systematically calibrate the eco-physiological parameters based on the algorithms of DSSAT that simulate the dynamic bio-physiological processes of crop growth in daily time-step. We can then use the AEZ with the updated eco-physiological parameters to rapidly evaluate the effects of shifts in planting day and changes in the length of growth cycle. Moreover, the suitability zone information generated by AEZ provides an indispensable vehicle to facilitate the effective upscaling of the DSSAT model. Please note that model coupling must work hand-in-hand with data fusion in modeling crop growth dynamics and as a consequence, the incorporation of natural adaptation measures lead to a much enriched model coupling procedure than presented in Tian et al. $(2012,2014)$, as we will report in the methods section.

The simulation results show that in the absence of adaptation, climate change from the baseline of 1961-1990 to the PRECIS-A1B climate of 2050s would decrease the potential yield of soybean in its major growing areas. By contrast, simulations of DSSAT using AEZ-recommended LGC features of cultivars and the associated adaptive planting dates show that the risk of yield loss could be fully or partially mitigated across majority of grid-cells in the major soybean growing areas. This finding brings encouraging news to farmers and policy makers who are key stakeholders in dealing with the risks and uncertainty posed by climate change to 
This is the version of the article accepted for publication in Human and Ecological Risk Assessment: An International Journal published by Taylor \& Francis. Available at: http://dx.doi.org/10.1080/10807039.2016.1221308

Accepted Version downloaded from SOAS Research Online: http://eprints.soas.ac.uk/23026/

soybean production in China.

\section{DATA}

\section{Soil Data}

Soil data are extracted from Harmonized World Soil Database. This soil database has been developed by the Land Use Change and Agriculture Program of International Institute for Applied Systems Analysis, the Food and Agriculture Organization of the United Nations, and other partner organizations. This database provides reliable and harmonized soil information at the grid cell level for China. Soil is aggregated into topsoil $(0-30 \mathrm{~cm})$ and subsoil $(30-100 \mathrm{~cm})$ with a resolution of $1 \mathrm{~km} \times 1 \mathrm{~km}$. Information on the drainage rate, soil depth, bulk density, organic carbon, mechanic content, soil $\mathrm{pH}$, cation exchange capacity of the soil and clay fraction is directly extracted from the database.

\section{Climate Data and Scenario Generation}

Climate data of the baseline (1981-2010) are based on the observed daily climate data calculated from 743 meteorological stations by the Chinese Meteorological Data Center nationwide. Data include minimum and maximum air temperature, solar radiation, precipitation, and relative humidity. All these input data, as well as the coordinates, are imported to ArcGIS and then interpolated and resampled into $10 \mathrm{~km} \times 10 \mathrm{~km}$ spatial resolution grid data.

The regional climate model - Providing REgional Climate for Impacts Studies (PRECIS) - is applied to generate daily climate data under the A1B scenario of greenhouse gas emission. ${ }^{2}$ PRECIS is designed by the UK Hadley Centre to generate

\footnotetext{
${ }^{2}$ Crop growth is very sensitive to local climate conditions and therefore, we need to use climate models with the finest spatial resolution, better representing the local land surface variables which affect the regional climate and internal climate variations, and being validated for China. The regional
} 
This is the version of the article accepted for publication in Human and Ecological Risk Assessment: An International Journal published by Taylor \& Francis. Available at: http://dx.doi.org/10.1080/10807039.2016.1221308

Accepted Version downloaded from SOAS Research Online: http://eprints.soas.ac.uk/23026/

detailed climate change predictions at a $50 \times 50 \mathrm{~km}$ scale. PRECIS is driven by initial and boundary conditions computed with HadCAM3, which is the updated version of the atmospheric component of the Hadley Centre Coupled Ocean-Atmosphere GCM-HadCM3. Xu et al. (2006) conduct a validation test on the applicability of the PRECIS model to the Chinese climate by comparing historical temperature and rainfall data over China for 1961-1990, with modeled data for this baseline period. The test shows a generally good agreement between observed and simulated data. The spatial correlation coefficient between model simulation and observation for the baseline run is 0.95 for annual temperature and 0.75 for annual precipitation, respectively. This test provides confidence in the prediction results of PRECIS for China's climate in the 21 st century under the future scenarios of greenhouse gas emission. The comparative advantage of the PRECIS simulations has also confirmed by others (e.g., Jordan et al. 2014; Wang et al. 2014). In this study, PRECIS is run in a geographical window covering China to simulate changes in precipitation, daily temperatures (minimum and maximum), wind speed, relative humidity, and solar radiation. The daily climate data simulation covers the period of present/baseline (1961-1990) and future (1991-2100).

\section{Soybean Observation Data}

Data on soybean growing and management are collected mainly for Northeast China $\left(38^{\circ}-56^{\circ} \mathrm{N}, 120^{\circ}-135^{\circ} \mathrm{E}\right)$ and the Huang-Huai-Hai Plain $\left(32^{\circ}-40^{\circ} \mathrm{N}\right.$,

climate model of PRECIS has been the top choice from the above perspectives. In contrast, General Circulation Modes (GCMs) which incorporate RCP scenarios have not yet validated for China and all have much coarse spatial resolution. However, it is worth noting that RCP scenarios have not yet been incorporated in PRECIS regional climate model. This status in regional climate modeling restricts our choice. This research team has also compared the effects of PRECIS-A1B, PRECIS-A2 and PRECIS -B2 on agro-climatic conditions of Chinese agriculture in terms of thermal regime, evapotranspiration, humidity index, and length of growing period (Tian et al. 2014), it is found that while the significant divergence does appear for the 2080 s, their effects in the 2050s are not significantly different. Given the space limitation, in this manuscript, we report the results under PRECIS-A1B only. 
This is the version of the article accepted for publication in Human and Ecological Risk Assessment: An International Journal published by Taylor \& Francis. Available at: http://dx.doi.org/10.1080/10807039.2016.1221308

Accepted Version downloaded from SOAS Research Online: http://eprints.soas.ac.uk/23026/

$114^{\circ}-121^{\circ} \mathrm{E}$ ), two major soybean production regions in China. The sown acreage and total production in Northeast China account for $33 \%$ and $44 \%$ of the national total, respectively. Approximately $30 \%$ of national soybean output is produced in the Huang-Huai-Hai Plain (Liu et al. 2008). Observation datasets of soybean production at the 13 soybean sites for 1981-2011 are collected from the China Meteorological Administration. This site-specific dataset includes basic information of sites (e.g., name, longitude, and latitude), cultivation information (e.g., variety, maturity category, and tillage method), details of the growth and development dates (e.g., sowing, emergence, anthesis, and maturity), yield-related information (e.g., density, grain weight, total yield, and straw weight), and major management measures (e.g., fertility, irrigation, and harvest) for each planting year. Table 1 reports the basic information of the observation sites. Seven of the 13 sites are located in Northeast China and all of them have detailed soybean cultivation records for 19 or more years.

Table1. Basic information of the observation sites

\begin{tabular}{lllllc}
\hline Province & Site & Longitude & Latitude & Years & $\begin{array}{c}\text { Length of growth } \\
\text { cycle (days) }\end{array}$ \\
& & & & $1983-2011$ & 137 \\
Heilongjiang & Bayan & 127.35 & 46.08 & $1981-2011$ & 134 \\
& Dedu & 126.15 & 48.47 & $1990-2011$ & 145 \\
Liaoning & Nenjiang & 125.23 & 49.17 & $1990-2000,2002-2009$ & 134 \\
& Fuxin & 121.72 & 42.08 & $1990-2009$ & 131 \\
Jilin & Gaizhou & 122.35 & 40.42 & $1990-2011$ & 135 \\
Inner Mongolia & Zhalantun & 122.73 & 48.00 & $1986-2011$ & 143 \\
Hebei & Huanghua & 117.35 & 38.37 & $1991-2011$ & 135 \\
Henan & Guoying & 114.40 & 33.75 & $1994-2011$ & 117 \\
Shandong & Juxian & 118.83 & 35.58 & $1990-1992$ & 89 \\
Jiangsu & Fengxian & 116.58 & 34.68 & $1998-2009$ & 103 \\
Anhui & Mengchen & 116.53 & 33.28 & $1992-2009$ & 103 \\
\hline
\end{tabular}

\section{METHODS TO COUPLE DSSAT AND AEZ MODEL}


This is the version of the article accepted for publication in Human and Ecological Risk Assessment: An International Journal published by Taylor \& Francis. Available at: http://dx.doi.org/10.1080/10807039.2016.1221308

Accepted Version downloaded from SOAS Research Online: http://eprints.soas.ac.uk/23026/

The two main models used in this work, namely, DSSAT and AEZ, have different modeling focuses. DSSAT can simulate the growth and development of crops; the soil water, carbon and nitrogen processes in the crop growth cycle; and the effect of management practices on crop growth in a daily time-step and at the site scale. The Generalized Likelihood Uncertainty Estimation (GLUE) module of DSSAT can generate genotype-specific coefficients. GLUE is a Bayesian estimation method that uses Monte Carlo sampling from prior distributions of the coefficients and a Gaussian likelihood function to determine the best coefficients based on the observation data, which has been widely used in crop model and hydrological model (Assumaning and Chang 2014; Chang and Sayemuzzaman 2014; Wang et al. 2015).. Both the GLUE and the Markov Chain Monte Carlo (MCMC) methods are popular for the calibration of cultivar coefficients. The popularity of GLUE can be largely attributed to its conceptual simplicity, relatively ease of implementation, and its capability to handle different error structures and models without major modifications to the method itself (Blasone et al. 2008). The MCMC would be more accurate than GLUE (He et al. 2010) but considerably more time consuming and difficult to implement.

Given that DSSAT is a site-based model, problems arise when applying DSSAT simulations to the neighboring areas of the site owing to DSSAT's very demanding data requirements and the issue of parameters suitability. In contrast, AEZ employs relatively simple but robust crop models and provides standardized crop-modeling and environmental matching procedure to identify crop-specific limitations of prevailing climate, soil and terrain resources under the assumed levels of inputs and management 
This is the version of the article accepted for publication in Human and Ecological Risk Assessment: An International Journal published by Taylor \& Francis. Available at: http://dx.doi.org/10.1080/10807039.2016.1221308

Accepted Version downloaded from SOAS Research Online: http://eprints.soas.ac.uk/23026/

conditions. The standardized crop-modeling and environmental matching procedure makes AEZ well suited for crop productivity assessment at regional, national and global scales (cf., among others, Velthuizen 2007; Fischer 2009; Fischer and Sun 2001; Gohariet al. 2013; Masutomi et al. 2009; Tubiello and Fischer 2007). Given a set of key crop eco-physiological parameters, which are specified as Land Utilization Units (LUTs) in AEZ, the AEZ model can select the specific planting date and the LGC feature of cultivar that are associated with maximum potential yield. Such selected planting date and LGC can be taken as the projected natural adaptation measures. Nevertheless, default soybean eco-physiological parameters in AEZ model are consolidated via literature review and expert opinion rather than model-based calibration, and thus they are limited and cannot match the richness of soybean farming patterns in China.

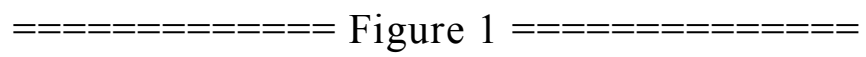

In this study, we integrate the advantages of the DSSAT and AEZ models and established a cross-scale model coupling procedure as presented in Figure 1. The procedure takes the following 5 steps. (1) The soybean cultivar parameters are calibrated by applying the DSSAT-GLUE procedure to the observations data on soybean growth at each of the 13 stations. (2) The LUT set of AEZ is extended by translating cultivar parameters obtained in (1) into the LUT-parameters of AEZ. AEZ run based on original default LUT set is denoted as $\mathrm{AEZ}_{0}$ and that based on the updated LUT set is denoted as $\mathrm{AEZ}_{1}$. Please note that $\mathrm{AEZ}_{1}$ already embraces the two natural adaptation measure of utilizing the best plating date and most suitable length of growth 
This is the version of the article accepted for publication in Human and Ecological Risk Assessment: An International Journal published by Taylor \& Francis. Available at: http://dx.doi.org/10.1080/10807039.2016.1221308

Accepted Version downloaded from SOAS Research Online: http://eprints.soas.ac.uk/23026/

cycle within the updated LUT set. The first run of DSSAT upscaling based on the observed cropping calendars and the matching of cropping-system zones and the observation sites is denoted as $\operatorname{DSSAT}_{0}$. (3) The similarity between two yields generated by $\mathrm{DSSAT}_{0}$ and $\mathrm{AEZ}_{1}$ at the grid-cell level under the baseline climate provides an observation-based verification of the AEZ model, which is usually absent in the AEZ literature. (4) The planting date and the LGC feature of cultivar which result in the maximum attainable yield are extracted from the $\mathrm{AEZ}_{1}$ model and imported into DSSAT as the adaptive planting date and LGC. The second run of DSSAT upscaling with the adaptive planting dates and LGC is denoted as DSSAT ${ }_{1}$. (5) The yield-loss risks posed by climate change can be quantified by comparing the results of $\mathrm{DSSAT}_{0}$ between the baseline and 2050 climate. The risk-reduction effect of adopting adaptive planting dates and LGC can be quantified by comparing the results of $\operatorname{DSSAT}_{1}$ with the reference $\mathrm{DSSAT}_{0}$ under the 2050 s climate. $^{3}$

The upscaling of DSSAT is facilitated by cropping system zone owing to its relative homogeneity in climate, soil, and terrain conditions if compared with other zones. Considering that soybean sites do not present a one-to-one correspondence with the zones, we reclassify the cropping system zones in accordance with the location of sites to best utilize the site-based observation records. The limitation of $\mathrm{AEZ}_{0}$ is revealed by comparing its simulation results with the observations at the sites. The

\footnotetext{
3 It is worth highlighting that because $\mathrm{AEZ}_{0}$ shows a poor fit with the observed LGC choices as we will show in the next section, one cannot use the yield differences of $\mathrm{AEZ}_{0}$ between the baseline and 2050 climate as a quantification of the yield-loss risks posed by climate change. For the same reason, one cannot use the yield differences between $\mathrm{AEZ}_{1}$ and $\mathrm{AEZ}_{0}$ under the 2050 s climate to quantify the risk-reduction effect of adopting adaptive planting dates and LGC.
} 
This is the version of the article accepted for publication in Human and Ecological Risk Assessment: An International Journal published by Taylor \& Francis. Available at: http://dx.doi.org/10.1080/10807039.2016.1221308

Accepted Version downloaded from SOAS Research Online: http://eprints.soas.ac.uk/23026/

comparison shows that the LUT set in $\mathrm{AEZ}_{0}$ does not contain the cultivars with a length of growth cycle at about 150 days and the $\mathrm{AEZ}_{0}$ run does not reflect the prevalent multi-cropping pattern in the Huang-Huai-Hai Plain. This finding justifies the adoption of steps (1) and (2) above so that we can enrich the LUT set of AEZ and take into account multi-cropping practice of local farmer in the simulation runs of $\mathrm{AEZ}_{1}$ and DSSAT ${ }_{1}$

\section{RESULTS AND ANALYSIS}

\section{Determining Genetic Coefficients via DSSAT Calibration}

In order to determine cultivar coefficients which are able to sustain maximum attainable yield under ideal management conditions, we assume that (a) the most suitable cultivar is adopted in each observation site, (b) there is no water and nutrient limitation during the growing period, and (c) the control of pests and diseases is fully effective. This means that automatic irrigation and fertilizer applications are set in the DSSAT calibration process to prevent potential water or nitrogen stress during the plant growing period. This also means that we should take the trustworthy record of maximum yield as the anchor of yield fitting in the DSSAT calibration. In addition, because rigorous estimation of crop phenology is crucial for the successful validation of crop models on site (Mall et al. 2004), we strictly follow the trustworthy records of the observed crop calendars in the calibration so that the calibration and simulation of DSSAT fit well with the observed phonological stages and maximum attainable yields. The GLUE module of DSSAT is employed to select the values of genetic coefficients at each station (cf. Tian et al. 2014 for technical details). 
This is the version of the article accepted for publication in Human and Ecological Risk Assessment: An International Journal published by Taylor \& Francis. Available at: http://dx.doi.org/10.1080/10807039.2016.1221308

Accepted Version downloaded from SOAS Research Online: http://eprints.soas.ac.uk/23026/

Figure 2 demonstrates the satisfactory performance of the GLUE procedure. It shows the relationship between the predicted key phonological dates from DSSAT simulations using the GLUE-selected coefficient values and the real observations. The scatter diagram in Figure 2 indicates a strong correlation between the observed and simulated key phonological dates. The $\mathrm{R}^{2}$ values for the anthesis day and maturity day are 0.86 and 0.92 , respectively. Figure 2 indicates that the genetic coefficients we have selected via DSSAT-GLUE procedure can effectively capture the growth and development characteristics of soybean at these observation sites and their neighboring areas.

Figure 2 and Figure 3

\section{Enriching the LUT Parameters Set of AEZ}

Given a set of LUTs, the AEZ model can automatically calculate and select the cultivar type and planting date which are associated with the maximum attainable yield at each location. Therefore, richness of LUT set is critical for the performance of AEZ. The leading critical feature of a cultivar type in AEZ is the length of growth cycle (LGC). The original LUT set of $\mathrm{AEZ}_{0}$ contains three types of stylized LGCs as shown in Table 2 and Figure 3-B, whereas the observed LGCs at the 13 sites present four types of stylized LGCs as reported in Table 3 and Figure 3-A. Two differences in terms of geographical location of LGCs between $\mathrm{AEZ}_{0}$ and the observed data are worth highlighting. First, the cultivar with a LGC of 150 days is missing in the LUT set of $\mathrm{AEZ}_{0}$ (cf. Figure 3-B) although this cultivar has been planted in a large part of the Northeast China for many years as indicated in Figure 3-A. Second, in the Huang-Huai-Hai Plain, $\mathrm{AEZ}_{0}$ tends to select a longer LGP (135 days) than the 
This is the version of the article accepted for publication in Human and Ecological Risk Assessment: An International Journal published by Taylor \& Francis. Available at: http://dx.doi.org/10.1080/10807039.2016.1221308

Accepted Version downloaded from SOAS Research Online: http://eprints.soas.ac.uk/23026/

observed ones and this is because $\mathrm{AEZ}_{0}$ does not take into consideration the multi-cropping practice in the region where farmers put wheat and rice as the major crops and left a limited period for growing soybean as a secondary crop.

The first difference implies that the performance of AEZ can be improved by adding a new type of cultivar with a LGC for 150 days into the LUT set and by updating the cultivar parameters of other existing LGCs as recommended by the DSSAT-GLUE calibration and selection on the basis of the observed data. These updated parameters include harvest index (HI), maximum leaf area index (LAI), minimum appropriate accumulated temperature, subaltern minimum appropriate accumulated temperature, maximum appropriate accumulated temperature, and subaltern maximum appropriate accumulated temperature. Tables 3 and 2 show the details of the updating in soybean cultivar parameters.

Table 2. Soybean cultivar parameters in $\mathrm{AEZ}_{0}$

\begin{tabular}{llllllll}
\hline Variety & LGP & $\begin{array}{l}\text { Harvest } \\
\text { index }\end{array}$ & $\begin{array}{l}\text { Maximum } \\
\text { leaf area } \\
\text { index }\end{array}$ & $\begin{array}{l}\text { Minimum } \\
\text { appropriate } \\
\text { accumulated } \\
\text { temperature }\end{array}$ & $\begin{array}{l}\text { Subaltern } \\
\text { Minimum } \\
\text { appropriate } \\
\text { accumulated } \\
\text { temperature }\end{array}$ & $\begin{array}{l}\text { Maximum } \\
\text { appropriate } \\
\text { accumulated } \\
\text { temperature }\end{array}$ & $\begin{array}{l}\text { Subaltern } \\
\text { maximum } \\
\text { appropriate } \\
\text { accumulated } \\
\text { temperature }\end{array}$ \\
\hline 1 & 105 & 0.3 & 4.0 & 2200 & 1850 & 2600 & 3150 \\
2 & 120 & 0.35 & 2.5 & 2400 & 2000 & 3000 & 3600 \\
3 & 135 & 0.35 & 3.0 & 2600 & 2150 & 3400 & 4050 \\
\hline
\end{tabular}

Table 3. Soybean cultivar parameters in $\mathrm{AEZ}_{1}$

\begin{tabular}{llllllll}
\hline Variety & LGP & $\begin{array}{l}\text { Harves } \\
\text { t index }\end{array}$ & $\begin{array}{l}\text { Maximum } \\
\text { leaf area } \\
\text { index }\end{array}$ & $\begin{array}{l}\text { Minimum } \\
\text { appropriate } \\
\text { accumulated } \\
\text { temperature }\end{array}$ & $\begin{array}{l}\text { Subaltern } \\
\text { Minimum } \\
\text { appropriate } \\
\text { accumulated } \\
\text { temperature }\end{array}$ & $\begin{array}{l}\text { Maximum } \\
\text { appropriate } \\
\text { accumulated } \\
\text { temperature }\end{array}$ & $\begin{array}{l}\text { Subaltern } \\
\text { maximum } \\
\text { appropriate } \\
\text { accumulated } \\
\text { temperature }\end{array}$ \\
\hline 1 & 105 & 0.38 & 4.0 & 2100 & 1850 & 2800 & 3150 \\
2 & 120 & 0.37 & 4.2 & 2300 & 2000 & 3150 & 3500 \\
3 & 135 & 0.36 & 4.5 & 2500 & 2150 & 3450 & 3800 \\
4 & 150 & 0.35 & 4.5 & 2700 & 2300 & 3750 & 4100 \\
\hline
\end{tabular}


This is the version of the article accepted for publication in Human and Ecological Risk Assessment: An International Journal published by Taylor \& Francis. Available at: http://dx.doi.org/10.1080/10807039.2016.1221308

Accepted Version downloaded from SOAS Research Online: http://eprints.soas.ac.uk/23026/

The second difference suggests that the capacity of AEZ in simulating observed soybean farming practice can be strengthened by taking into account the pecking order of farmers' multi-cropping choices. This means that in the single-cropping and limited double-cropping zones, there is no restriction on LGC choices, or in other words, soybean farmers typically select, from Table 3, the LGC type that produces the highest attainable yield. In the double-cropping and double-cropping with rice zones, the choice set of LGC type is restricted to the two medium LGC types of 105 and 120 days. In the double rice-cropping, triple-cropping, and triple rice-cropping zones, the choice set contains only the LGC type of 105 days. Figure 3-C shows the LGC distribution chosen by the optimization procedure of AEZ1, which, in comparison with Figure 3-B, is much more consistent with Figure 3-A.

\section{Yield-Reduction Risk and the Mitigating Effect of the Two Adaptation Measures}

Baseline. Figure 4 presents the maximum attainable yields generated by $\mathrm{DSSAT}_{0}$ and $\mathrm{AEZ}_{1}$ under the baseline climate. The resolution of maps in Figures 4 and 5 is $10 \mathrm{~km} \times 10 \mathrm{~km}$. Figure 4 shows a good general match between two sets of results. However, there are also two main differences in the spatial distribution of the results. First, spatial variation of the $\mathrm{DSSAT}_{0}$ results is less than that of $\mathrm{AEZ}_{1}$ and yields of $\operatorname{DSSAT}_{0}$ are slightly higher than that of $\mathrm{AEZ}_{1}$ in Henan and Central Shandong provinces. This is due to the fact that the $\mathrm{DSSAT}_{0}$ model does not take into account the effect of the aspect and gradient of land slope, whereas the AEZ model does consider terrain constraints. Second, $\mathrm{AEZ}_{1}$ produces higher yield than $\mathrm{DSSAT}_{0}$ does in the northeast part of Heilongjiang Province. This is mainly due to that we do not have observation site there and $\mathrm{DSSAT}_{0}$ has to adopt cultivar parameters from a far-away site. By contrast, $\mathrm{AEZ}_{1}$ can make selections in each grid cell from the given LUT 
This is the version of the article accepted for publication in Human and Ecological Risk Assessment: An International Journal published by Taylor \& Francis. Available at: http://dx.doi.org/10.1080/10807039.2016.1221308

Accepted Version downloaded from SOAS Research Online: http://eprints.soas.ac.uk/23026/

parameter set. In terms of average yield in each cropping zone, the results of DSSAT $_{0}$ and $\mathrm{AEZ}_{1}$ are very similar under the baseline climate. The average yields across all areas concerned are $2788 \mathrm{~kg} / \mathrm{ha}$ from of $\mathrm{DSSAT}_{0}$ and $2796 \mathrm{~kg} / \mathrm{ha}$ from $\mathrm{AEZ}_{0}$, respectively. This similarity provides an observation-based strong verification for the suitability of $A E Z_{1}$. Such verification has been typically missing in the AEZ-related literature.

The Potential Yield-Reduction Risk. Figure 5 shows the yield difference between the baseline and the 2050s in terms of $\mathrm{DSSAT}_{0}$ run. In the $2050 \mathrm{~s}, \mathrm{DSSAT}_{0}$ projects a yield decrease in majority of the soybean production areas except for the north and east parts of the Northeast region. On average, the extent of the yield reduction is $678 \mathrm{~kg} / \mathrm{ha}$, which represents a yield loss rate of $24 \%$ in comparison with the baseline. In more details for the spatial distribution, the major areas with yield increase are located in the north and east parts of the Northeast China, whereas those with yield reduction are in the southwest part of the Northeast and the Huang-Huai-Hai Plain, including Hebei and Shandong provinces, north of Anhui and Jiangsu provinces. Thus, the total area can be divided into the area with opportunity and that with risk. In the Northeast China, the balance of the opportunities and risk leads to a yield decrease by $77 \mathrm{~kg} / \mathrm{ha}$. In the Huanghuai-Huai-Hai Plain, the yield decrease is $1406 \mathrm{~kg} / \mathrm{ha}$, indicating a very high level of yield-reduction risk.

$===========$ Figure $4-7============$

The Effect of the Two Adaptive Measurements. Figure 6 compares the yields predicted by $\operatorname{DSSAT}_{0}$ and by $\operatorname{DSSAT}_{1}$ under the $2050 \mathrm{~s}$ climate at each of the 13 sites. It 
This is the version of the article accepted for publication in Human and Ecological Risk Assessment: An International Journal published by Taylor \& Francis. Available at: http://dx.doi.org/10.1080/10807039.2016.1221308

Accepted Version downloaded from SOAS Research Online: http://eprints.soas.ac.uk/23026/

shows obvious yield increase at 10 of the 13 sites and at 6 of the 10 sites with yield increase, the extent of yield increase exceeds $500 \mathrm{~kg} / \mathrm{ha}$. Figure 7 further presents the yield differences between up-scaled $\operatorname{DSSAT}_{1}$ and $\operatorname{DSSAT}_{0}$ simulations under the 2050s climate. It shows that the yield-increase effect of the two natural adaptation measures would occur in vast majority areas of the major soybean production region. The yield increase is particularly strong in southwestern part of Heilongjiang Province and the whole Shandong Province where the adaption measures could lead to a yield increase by more than $1000 \mathrm{~kg} / \mathrm{ha}$. However, moderate yield reduction would still happen as shown by the red-orange color in few packet areas. On an overall average, the extent of yield increase would be about $856 \mathrm{~kg} / \mathrm{ha}$, which is more than overall average yield loss of $678 \mathrm{~kg} / \mathrm{ha}$ as predicted by $\mathrm{DSSAT}_{0}$.

\section{CONCLUSION AND DISSCUSTIONS}

In this research, we present a procedure to couple the site-scale DSSAT model and regional-scale AEZ model and show that the coupling enriches the eco-physiological parameters of the AEZ soybean LUTs. In the coupling process, we derive, calibrate, and validate the key cultivar parameters by using DSSAT at the observation sites. We fully utilize the ability of AEZ in rapidly evaluating the effects of shifts in planting day and changes in the length of growth cycle to generate the key crop-calendar information. This set of crop-calendar information enables DSSAT to simulate the effects of such adaptive measures as crop-calendar shifts.

The application of above model coupling method to the case of soybean production in China generates a set of insight findings. On the one hand, the simulations of $\operatorname{DSSAT}_{0}$ without adaptive measures indicate that climate change 
This is the version of the article accepted for publication in Human and Ecological Risk Assessment: An International Journal published by Taylor \& Francis. Available at: http://dx.doi.org/10.1080/10807039.2016.1221308

Accepted Version downloaded from SOAS Research Online: http://eprints.soas.ac.uk/23026/

between the baseline and 2050s would result in beneficial effects in the north and east parts of Northeast China and cause yield losses in other parts of the major soybean production regions of China. On the other hand, the simulations of $\operatorname{DSSAT}_{1}$ with adaptive planting date and length of growth cycle show that under the 2050 s climate, the average attainable yield could increase by $856 \mathrm{~kg} / \mathrm{ha}$ in comparison with the results of $\operatorname{DSSAT}_{0}$, which is more than sufficient to compensate the average yield loss of 678 $\mathrm{kg} / \mathrm{ha}$ as predicted by $\mathrm{DSSAT}_{0}$. This finding encourages active and systematic adaptations by farmers and policy makers in dealing with the risks and uncertainty posed by climate change to soybean production in China.

Two limitations are worth mentioning for future studies. First, the adaptive planting date is extracted from the optimal solutions of $\mathrm{AEZ}_{1}$ without a due consideration of the potential competing crop-calendar demand from major crops such as wheat or rice in multi-cropping zones. This limitation can be overcome once AEZ can fully accommodate multi-cropping practices in its optimization process. Second, in the DSSAT upscaling process, we apply the site-specific information on adaptive planting date and length of growth cycle to all grid cells in the same cropping-system zones. Future research should develop an automatic link at the grid-cell level for DSSAT to extract adaptive information from AEZ.

\section{REFERENCES}

Assumaning G A. Chang S 2014. State and Parameter Estimation in Three-Dimensional Subsurface Contaminant Transport Modeling using Kalman Filter Coupled with Monte Carlo Sampling. Journal of Environmental Informatics 24: $80-89$ 
This is the version of the article accepted for publication in Human and Ecological Risk Assessment: An International Journal published by Taylor \& Francis. Available at: http://dx.doi.org/10.1080/10807039.2016.1221308

Accepted Version downloaded from SOAS Research Online: http://eprints.soas.ac.uk/23026/

Blasone R S, Vrugt J A, Madsen H, Rosbjerg D, Robinson B A, Zyvoloski G A (2008). Generalized likelihood uncertainty estimation (GLUE) using adaptive Markov chain Monte Carlo sampling. Advances in Water Resources, 31(4): 630-648

Calzadilla A, Zhu T, Rehdanz K, et al. 2014. Climate change and agriculture: Impacts and adaptation options in South Africa. Water Resources and Economics 5: 24-48

Chang S Y, Sayemuzzaman M 2014. Using Unscented Kalman Filter in Subsurface Contaminant Transport Models. Journal of Environmental Informatics 23: 14-22

Chen C, Qian C, Deng A, et al. 2012. Progressive and active adaptations of cropping system to climate change in Northeast China. European Journal of Agronomy 38(1): 94-103

De Bruin J L, Pedersen P. 2008. Yield Improvement and Stability for Soybean Cultivars with Resistance to Ichinohe[J]. Agronomy journal 100(5): 1354-1359

Drager K H, Robertson T V. 2014. TIEMS DREVS Initiative: Disaster Resilience Establishment for Vulnerable Societies. Journal of Risk Analysis and Crisis Response 4(3): 133-140

FAO. 2010, 2013. Production Statistics (Rome: United Nations Food Agric Organ) available at: faostat.fao.org

Ferreira D B, Rao V B. 2011. Recent climate variability and its impacts on soybean yields in Southern Brazil. Theoretical and applied climatology 105(1): 83-97

Fischer G. 2009. World food and agriculture to 2030/50: how do climate change and bioenergy alter the long-term outlook for food, agriculture and resource availability? In: Proceedings of the Expert Meeting on How to Feed the World in 2050, 24-26 June. FAO, Rome, Italy: 1-49

Fischer G, Sun L. 2001. Model based analysis of future land-use development in China . 
This is the version of the article accepted for publication in Human and Ecological Risk Assessment: An International Journal published by Taylor \& Francis. Available at: http://dx.doi.org/10.1080/10807039.2016.1221308

Accepted Version downloaded from SOAS Research Online: http://eprints.soas.ac.uk/23026/

Agriculture Ecosystems \& Environment 85(1-3): 163-176

Fischer G, Velthuizen H V, Shah M, et al. 2002. Global Agro-ecological Assessment for Agriculture in the 21st Century: Methodology and Results. Journal of Henan Vocation-technical Teachers College 11(8): 371-374

Foley J A, DeFires R, Asner G P, et al. 2005. Global consequences of land use. Science 309(5734): $570-574$

Gohariet A, Eslamian S, Abedi-Koupaei J, et al. 2013. Climate change impacts on crop production in Iran's Zayandeh-Rud River Basin. Science of the Total Environment 442: 405-419

Hao H, Long P, Curtis S.2012. Attitudes of Property Owners to Climate Change Considerations and Their Effects on Future Property Values in Coastal Communities. Journal of Risk Analysis and Crisis Response 2(4): 285-291

Hao X Y, Han X, Hui J U, et al. 2010. Impact of climatic change on soybean production: a review. The journal of applied ecology 21(10): 2697-2706

Hao X Y, Lin E D, Yang J Z, et al. 2009. Effects of free air $\mathrm{CO}_{2}$ enrichment (FACE) on growth and yield of summer Soybean. Aata Ecologica Sinica 29(9): 4595-4603

He J, Jones J W, Graham W D, Dukes M D 2010. Influence of likelihood function choice for estimating crop model parameters using the generalized likelihood uncertainty estimation method. Agricultural Systems 103(5): 256-264

IPCC. 2013. Climate Change 2013: Summary for Policymakers. http://www.ipcc.ch/pdf/assessment-report/ar5/wg1/WG1AR5 SPM_FINAL.pdf

Jones J W, Hoogenboom G, Porter C H, et al. 2003. The DSSAT cropping system model. European journal of agronomy 18(3): 235-265

Jordan Y C, Ghulam A, Chu M L (2014). Assessing the Impacts of Future Urban Development Patterns and Climate Changes on Total Suspended Sediment Loading 
This is the version of the article accepted for publication in Human and Ecological Risk Assessment: An International Journal published by Taylor \& Francis. Available at: http://dx.doi.org/10.1080/10807039.2016.1221308

Accepted Version downloaded from SOAS Research Online: http://eprints.soas.ac.uk/23026/

in Surface Waters Using Geoinformatics. Journal of Environmental Informatics 24: $65-79$

Kastner T, Rivas M J, Koch W, et al. 2012. Global changes in diets and the consequences for land requirements for food. Proceedings of the National Academy of Sciences of the USA 109(18): 6868-6872

Liu X, Jin J, Wang G, et al. 2008. Soybean yield physiology and development of high-yielding practices in Northeast China. Field Crops Research 105(3): 157-171

Mall R K, Lal M, Bhatia V S, et al. 2004. Mitigating climate change impact on soybean productivity in India: a simulation study. Agricultural and forest meteorology 121(1-2): 113-125

Masuda T, Goldsmith P D. 2009a. World Soybean Demand: An Elasticity Analysis and Long-Term Projections//Annual Meeting, July 26-28, 2009, Milwaukee, Wisconsin. Agricultural and Applied Economics Association

Masutomi Y, Takahashi K, Harasawa H. et al. 2009. Impact assessment of climate change on rice production in Asia in comprehensive consideration of process/parameter uncertainty in general circulation models. Agriculture, Ecosystems and Environment 131(3-4): 281-291

Marzban F, Ghasemi O, Mobasser H R. 2011. Effects of Changes in Source-Sink Relation in Different Planting Dates on Yield and Yield Components of Soybean Cultivars. International Journal of Biology 3 (3): 90-93

Sahu N C, Mishra D. 2013. Analysis of Perception and Adaptability Strategies of the Farmers to Climate Change in Odisha, India. APCBEE Procedia 5: 123-127

Setiyono T D, Weiss A, Specht J. et al. 2007. Understanding and modeling the effect of temperature and daylength on soybean phenology under high-yield conditions. Field Crops Research 100(2-3): 257-271 
This is the version of the article accepted for publication in Human and Ecological Risk Assessment: An International Journal published by Taylor \& Francis. Available at: http://dx.doi.org/10.1080/10807039.2016.1221308

Accepted Version downloaded from SOAS Research Online: http://eprints.soas.ac.uk/23026/

Shi C, Jin Z, Ge D, et al. 2001. Gradual effects of climate change on food production and adaptation strategies in the middle and lower valley of Yangtze River. Jiangsu Academy of Agricultural Sciences 17(1): 1-6

Sinclair T R, Purcell L C, King C A, et al. 2007. Drought tolerance and yield increase of soybean resulting from improved symbiotic N2 fixation. Field Crops Research 101(1): $68-71$

Thomas J M G, Boote K J, Allen L H. et al. 2003. Elevated temperature and carbon dioxide effects on soybean seed composition and transcript abundance. Crop Science 43(4): 1548-1557

Tian Z, Yang X, Sun L, et al. 2014a. Agroclimatic conditions in China under climate change scenarios projected from regional climate models. International Journal of Climatology 34: 2988-3000

Tian Z, Zhong H, Shi R, et al. 2012. Estimating potential yield of wheat production in China based on cross-scale data-model fusion. Frontiers of Earth Science 6(4): $364-372$

Tian Z, Zhong H, Sun L, et al. 2014b. Improving performance of Agro-Ecological Zone (AEZ) modeling by cross-scale model coupling: An application to japonica rice production in Northeast China. Ecological Modelling 290: 155-164

Tubiello F N, Fischer G 2007. Reducing climate change impacts on agriculture: global and regional effects of mitigation, 2000-2080. Technological Forecasting and Social Change 74: 1030-1056

Velthuizen H V, Huddleston B, Fischer G, et al. 2007.Mapping biophysical factors that influence agricultural production and rural vulnerability. Environment and Natural Resources Series 11, Food and Agriculture Organization of the United Nations, Rome. Available at: http://www.fao.org/docrep/010/a1075e/a1075e00.htm. 
This is the version of the article accepted for publication in Human and Ecological Risk Assessment: An International Journal published by Taylor \& Francis. Available at: http://dx.doi.org/10.1080/10807039.2016.1221308

Accepted Version downloaded from SOAS Research Online: http://eprints.soas.ac.uk/23026/

Wang, S, Huang G H, Lin Q G, et al. 2014. Comparison of interpolation methods for estimating spatial distribution of precipitation in Ontario, Canada. International Journal of Climatology 34: 3745-3751

Wang S, Huang G H, Huang W, et al. 2015. A fractional factorial probabilistic collocation method for uncertainty propagation of hydrologic model parameters in a reduced dimensional space. Journal of Hydrology 529: 1129-1146

Xiao G, Zhang Q, Wang J. 2007. Impact of global climate change on agro-ecosystem: a review. Chinese journal of applied ecology 18(8): 1877-1885

$\mathrm{Xu}$ Y, Yong Z, Lin E, et al. 2006. Analyses on the climate change responses over China under SRES B2 scenario using PRECIS. Chinese Science Bulletin 51(18): $2260-2267$

Yin J, Gao H, Pei W. 2011. A Study on Food Safety Risk Analysis under the Condition of Traditional Agriculture. Journal of Risk Analysis and Crisis Response 1 (2): $118-125$ 
This is the version of the article accepted for publication in Human and Ecological Risk Assessment: An International Journal published by Taylor \& Francis. Available at: http://dx.doi.org/10.1080/10807039.2016.1221308

Accepted Version downloaded from SOAS Research Online: http://eprints.soas.ac.uk/23026/

Figure1. Procedure of the model coupling

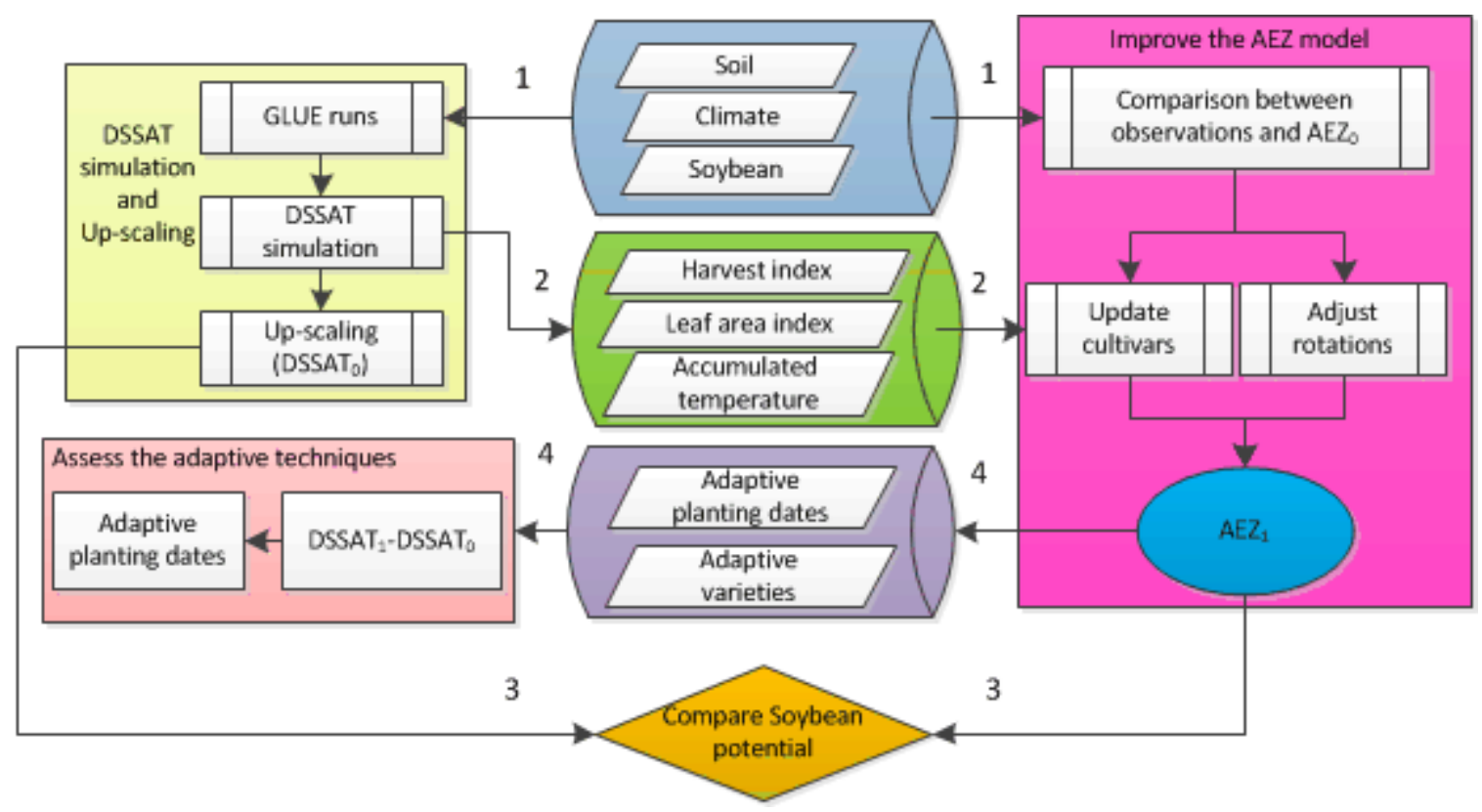

Figure 2. Correlation between observed and simulate anthesis day (left) and maturity day (right)
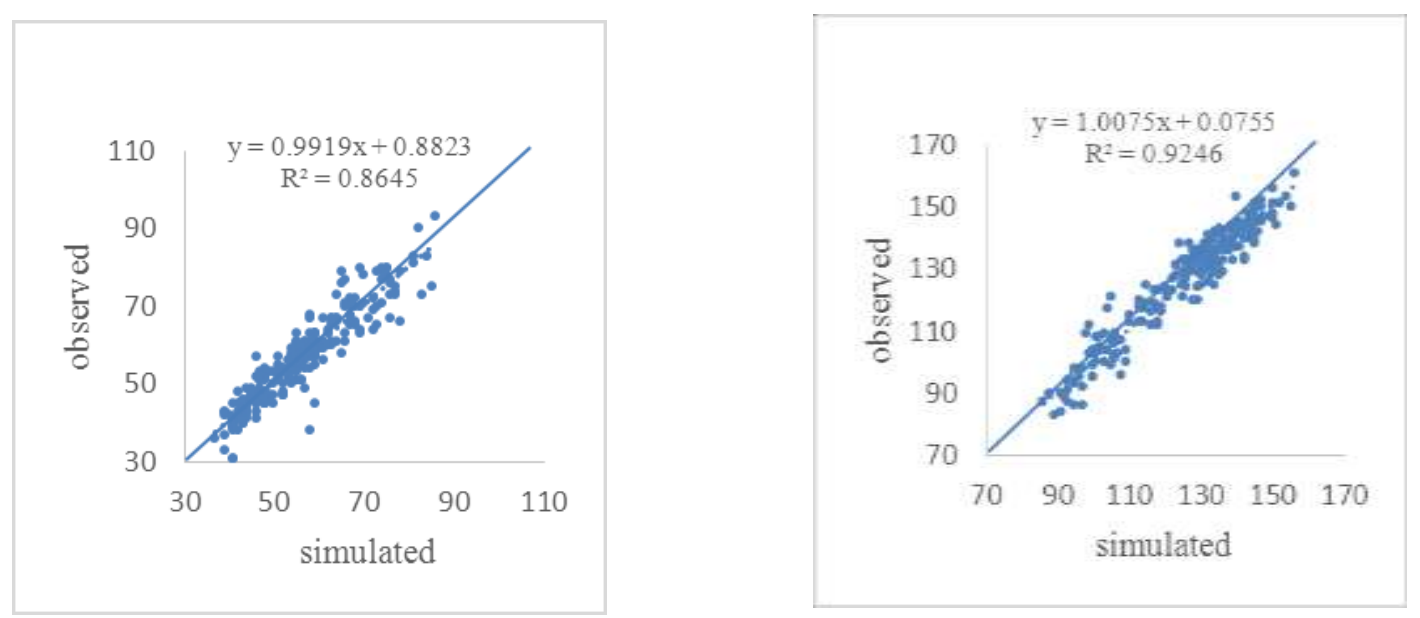
This is the version of the article accepted for publication in Human and Ecological Risk Assessment: An International Journal published by Taylor \& Francis. Available at: http://dx.doi.org/10.1080/10807039.2016.1221308

Accepted Version downloaded from SOAS Research Online: http://eprints.soas.ac.uk/23026/

Figure 3.The length of growth cycle from observations (A), $\mathrm{AEZ}_{0}(\mathrm{~B})$ and the $\mathrm{AEZ}_{1}(\mathrm{C})$

A

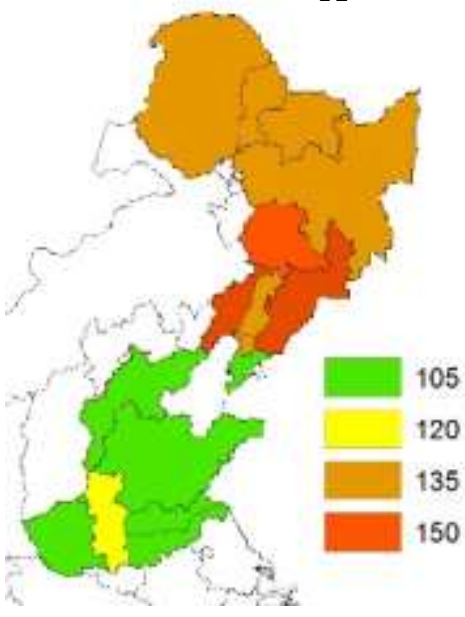

$\mathrm{B}$

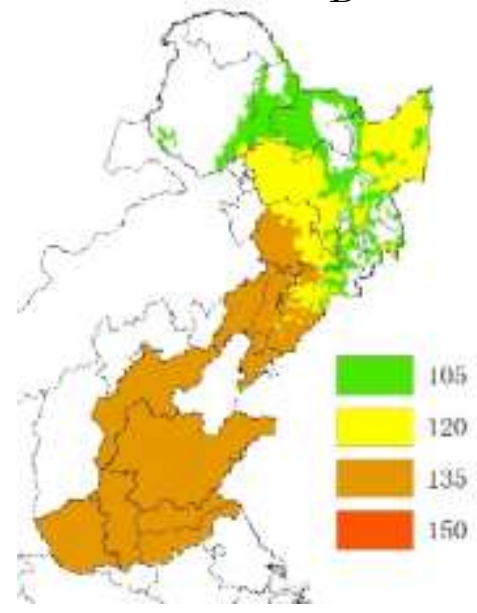

$\mathrm{C}$

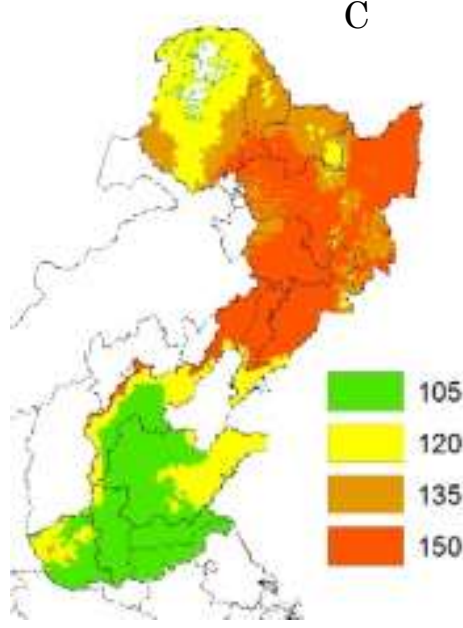

Figure 4. Yields under the baseline climate: $\operatorname{DSSAT}_{0}(\mathrm{~A})$ versus $\mathrm{AEZ}_{1}(\mathrm{~B})(\mathrm{kg} / \mathrm{ha})$
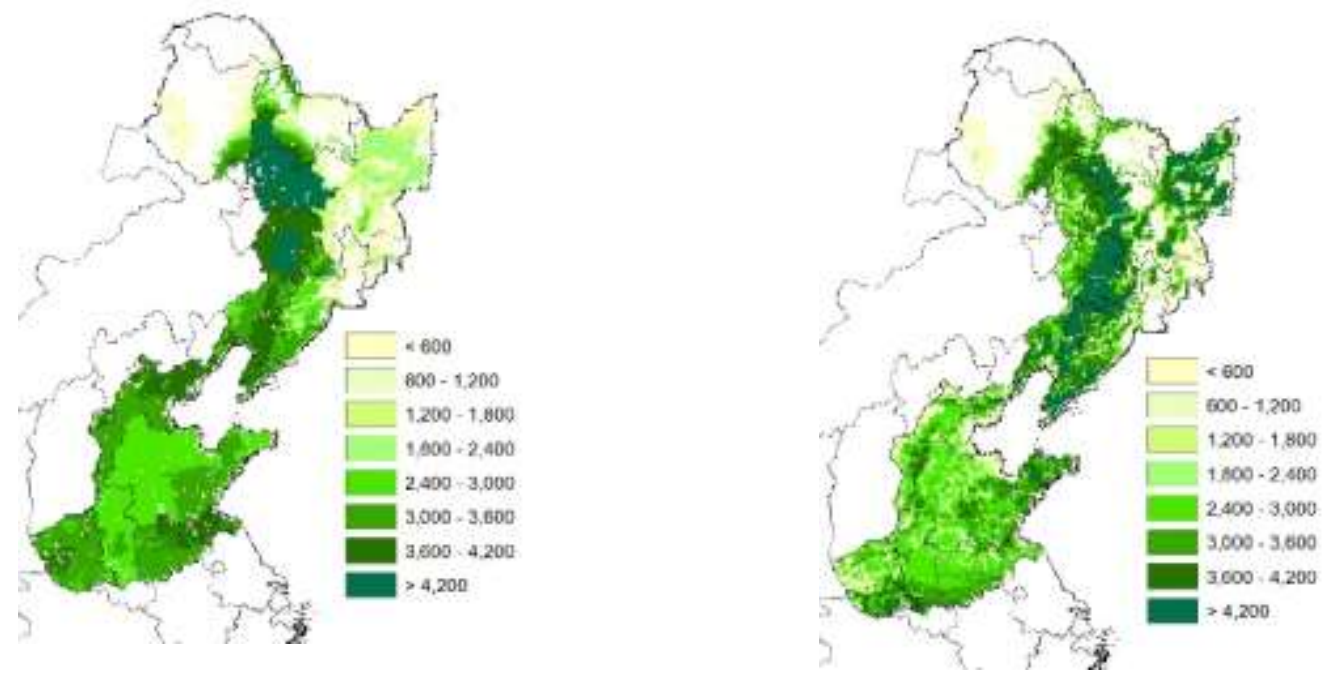
This is the version of the article accepted for publication in Human and Ecological Risk Assessment: An International Journal published by Taylor \& Francis. Available at: http://dx.doi.org/10.1080/10807039.2016.1221308

Accepted Version downloaded from SOAS Research Online: http://eprints.soas.ac.uk/23026/

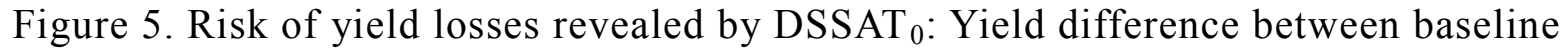
and $2050 \mathrm{~s}(\mathrm{~kg} / \mathrm{ha})$

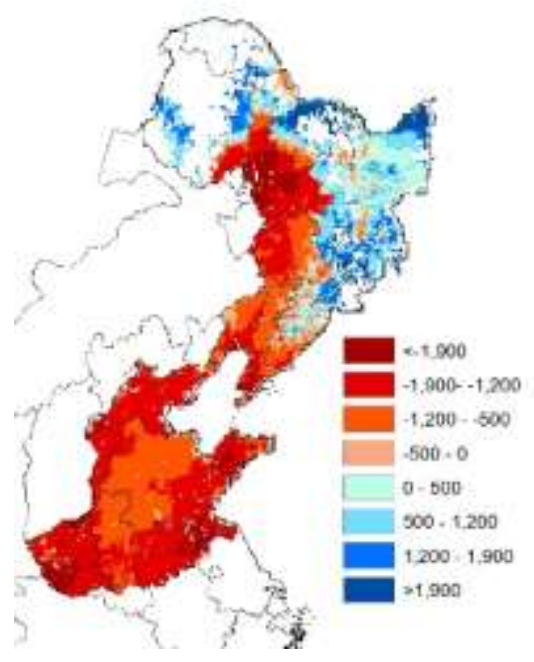

Figure 6. Yield comparison between $\operatorname{DSSAT}_{0}$ and $\operatorname{DSSAT}_{1}$ simulations under the 2050s climate, by sites $(\mathrm{kg} / \mathrm{ha})$

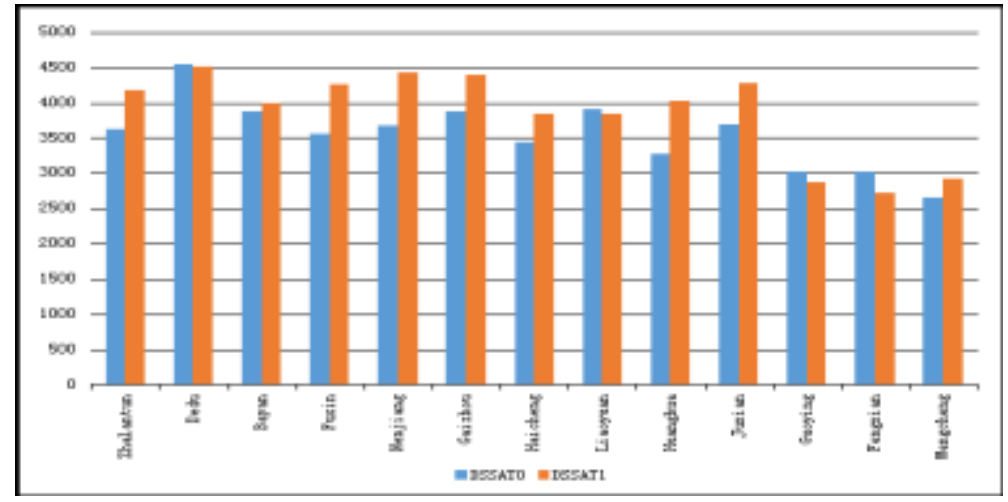


This is the version of the article accepted for publication in Human and Ecological Risk Assessment: An International Journal published by Taylor \& Francis. Available at: http://dx.doi.org/10.1080/10807039.2016.1221308

Accepted Version downloaded from SOAS Research Online: http://eprints.soas.ac.uk/23026/

Figure 7. The Effect of the two adaptive measurements: Yield differences between $\mathrm{DSSAT}_{1}$ and $\mathrm{DSSAT}_{0}$ under the 2050s climate $(\mathrm{kg} / \mathrm{ha})$

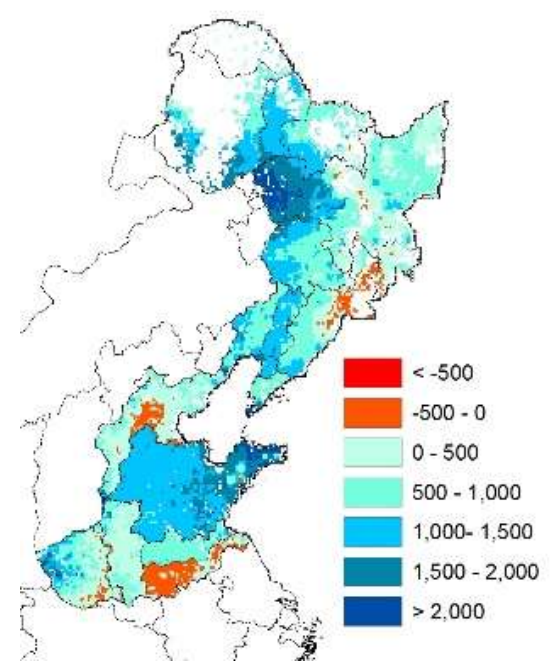

